\title{
MODERATING EFFECT OF ENTERPRISE RISK MANAGEMENT ON THE RELATIONSHIP BETWEEN BOARD STRUCTURES AND CORPORATE PERFORMANCE
}

\author{
Saddam Ali Shatnawi ${ }^{1}$ \\ $\mathrm{PhD}$ candidate, \\ Faculty of Economics and Muamalat, Universiti Sains Islam Malaysia (USIM) \\ Bandar Baru Nilai, 71800, Nilai, Negeri Sembilan, Malaysia \\ (Email: saddamshatnawiusim@yahoo.com) \\ Mustafa Mohd Hanefah ${ }^{2}$ \\ Professor of Accounting \\ Monther Yahiya Sobhi Eldaia ${ }^{3}$ \\ $\mathrm{PhD}$ candidate
}

Accepted date: $30-09-2018$

Published date: 08-07-2019

To cite this document: Shatnawi, S. A., Hanefah, M. M., \& Eldaia, M. Y. S. (2019). Moderating Effects of Enterprise Risk Management on The Relationship Between Board Structures and Corporate Performance. International Journal of Entrepreneurship and Management Practices, 2 (6), 01-15.

DOI: $10.35631 /$ IJEMP.26001

Abstract: Risk encroachment into Corporate Governance $(C G)$ remains a continuous process that required an efficient and long-term solution. Using enterprise risk management (ERM) as a moderating variable on the relationship between board structures and corporate performance is remains an area unexploited in $C G$ research. This relationship can effectively measure by the extent of ERM interactions between board structures and corporate performance. Despite various studies on CG mechanisms, firm performance, ERM implementation level, and gender diversity, the empirical results appeared inconclusive and the findings are inconsistent. None of the studies have addressed the role play by ERM as a moderator between director ownership, the board size, board independence, the total number of women on the board, number of Muslim directors on the board, and firm performance. It is demonstrated that the ERM has the potential to moderate between the different board structures and corporate performance, and this moderation has never been reported in the literature. It is expected that this ERM moderation may considerably improve corporate performance by determining the strength or weakness of the relationship between board structures and firm performance. Thus, this paper, with regards to available literature, conceptualized that 'ERM' moderates the relationship between Board Size, Board Independence, Director Ownership, Total Women in the Board, Muslim directors on the Board, and corporate performance.

Keywords: Board Structures, Corporate Performance, ERM, Moderating, Relationship 


\section{Introduction}

Corporate scandals and the collapse of world top corporate organizations have prompted researchers and experts to reconsider the connection between risk management enterprises (ERM) and organizational performances (Giroux, 2008). Firms are expected to recurrently review and develop novel approaches that will enhance their working efficacies in order to remain a competitive environment (Du, 2018). These firms may need to explore fresh areas of emerging risks and develop a more robust risk management approach. Based on the complexities of CG structures and enterprise, the attempt to deal with risk disclosures has become critical to the firms' existence (Boniface \& Ibe, 2012). Intrinsically, the failure of firms to be positive in risk evaluation, moderation, and control had led to poor firm performance (Dabari \& Saidin, 2016a).

Corporate governance structures are vital for the efficient functioning of firms and enhance performance (Nyatichi, 2016; Savitri, 2016). The board of directors as part of CG structure are anticipated to perform functions that include monitoring of management to moderate agency risks, costs, employing, and discharging of management officers, as well as providing tactical path for the firm to improve its performance (Zemzem \& Ftouhi, 2013; Affes \& Sardouk, 2016; Armeanu et al., 2017). Boards also have a duty to induct managerial change and expedite practices that support the corporate mission (Affes \& Sardouk, 2016). Moreover, the boards seek to safeguard the stakeholder's interest in a progressively competitive environment by minimizing all level of risks in the organization while sustaining managerial effectiveness in the quest for maximum firm performance (Dabari \& Saidin, S2016a). CAS (2003) expressed ERM as a domain that permits an organization to evaluate, control, utilize, fund, and monitor risks from all sources for the sole purpose of boosting the shareholder value. ERM pattern is regarded as a vital board strategic policy in decision making (COSO, 2004). Since, it is a holistic process in detecting potential risks encountering organizations and selecting applicable responses consistent with the risk appetite of the enterprise. Hence, an effective board of directors is needed to realize this sole purpose through moderating role of ERM thereby resulting in improved firm performance. As a result of last global financial crisis and many scandals (Battaglia et al., 2016; Berger et al., 2016), directors and shareholders are now presented with challenges not only complexity of monitoring and accountability, but also on functional ERM moderation challenges and its liability (Bromiley et al., 2015). A functional ERM moderation can improve risk responsiveness in a firm thereby improves the decision-making process, which can, in turn, increase firm value maximization (Miloš Sprčić et al., 2017). Until date, there is no sufficient evidence on ERM moderating role on board structures and corporate performance. Therefore, this paper proposes a conceptual framework to examine the moderating effect of ERM on selected board structures (board size, board independence, director ownership, the total number of women on the board, and Muslim directors on the board) and corporate performance.

\section{Literature Review}

Enterprise risk management has received increased International attention and has become a subject of interest to the stakeholders in the business. The positioning of ERM in the firms, particularly the financial industry can offer the required monitoring mechanism to efficiently address potential risk disclosures that can threaten the achievement of the aims of an enterprise (Bromiley et al., 2015; Cohen et al., 2017). Hence, the fundamental of ERM adoption is to 
safeguard that firm purpose of nurturing the value of stakeholders is realized. The ERM has very good potential to moderate firm performance through the CG mechanisms especially financial processes, which in turn, can result in raising the stakeholders' values (Annamalah et al., 2018; Yang et al., 2018). This process can only be achieved when the unforeseen threats are adequately managed by the board of directors to maximize firm performance (Affes \& Sardouk, 2016; Armeanu et al., 2017). Though, the boards can be significantly affected by their size, independence, ownership, total number of women on them, and faith i.e. the total Muslim directors on the board (Bashir \& Asad, 2018; Tulung \& Ramdani, 2018). The board of directors is the highest decision-making entity of a corporate and are responsible for monitoring the firm's management, and morally and legally responsible for the stakeholders (Jizi \& Nehme, R2018). However, in response to unanticipated organizational threats, some studies reported direct influence of ERM on corporate performance (Ugwuanyi \& Ibe, 2012; Callahan and Soileau 2017; Florio and Leoni 2017; Soliman et al., 2018; Zou and Hassan 2017) while other established that the relationship between ERM and corporate performance may be influenced by internal factors (Khan and Ali 2017).

The most important internal factors that impact the management ability to monitor moderation of ERM is the size of the board of directors (Tulung \& Ramdani, 2018). There is no single acceptable "size" for the board (Reddy, Locke, and Scrimgeour, 2010). However, there are different opinions on the influence of board size on firm performance. Some proposed that smaller boards improve firm performance (Jensen 1993; Yermack, 1996), while others indicated that larger boards are better for enhancing firm performance through risks moderation as a result of conflicts of interest (Jensen and Meckling, 1976; Anderson et al., 2004). In order to improve firm performance, Lipton and Lorsch (1992) have proposed between seven to nine individuals as ideal board size. According to a report, this board size can ensure better coordination, accountability, reduce the free-riding problem, ERM, and faster decision-making (Tornyeva and Wereko, 2012; Rao and Tilt, 2016). Though, Jensen and Meckling (1976) debated that bigger boards sized can reduce the cost of the agency as a result of low management performance which, in turn, can enhance financial results.

Apart from the impact of board size, board independence also has a strong influence ERM moderation on corporate performance. Independent directors are not employees of the firm, where their main role is to monitor the performance and activities of executive directors and management (Fuzi et al., 2016). Remarkably, the board of directors that lack the independent judgment of potential risks within the organization and its managers, places the interests of investors at jeopardy (Hermalin and Weisbach, 1988). The board independent add absolutely to the firm performance through ERM in moderating the conflicts of interests thereby decreases administrative delineation and repossession of fixed resources (Lee, 2012). The likelihood of bankruptcy due to poor ERM adoption can be less when there are independent directors within a firm.

The director independence comes along with the director ownership which tends to have a direct effect on firm performance since director ownership can result in a conflict of interests between these directors and firm stakeholders thereby weaken ERM within the firm. Pagach and Warr (2011) depict that director ownership is influence by ERM adoption in US firms, especially when the firms are larger, more volatile, and have greater institutional ownership. However, these studies have not addressed the direct moderating role play by ERM between director ownership and firm performance. All the studies focus on the general effect of managerial ownership on firm 
performance. Tahir and Razali (2011) assessed the relationship between ERM and firm value in Malaysian public listed firms. They found a positive relationship between ERM, however, ownership shows no significant relationship with firm value, where the size and profitability have a negative and significant impact on the relationship with firm value.

Furthermore, aside from board size, board independence, and director ownership that are considered highly significant on firm performance, the gender is presently the most debated component of board structure issues (Bøhren \& Staubo, 2016). The presence of women directors on board is getting increasing consideration (Setó-Pamies, 2015). Based on agency theory standpoint, gender cannot impact the efficacy of a board (Bosse \& Phillips, 2016). However, bearing in mind that gender can explicate differences in behavior and abilities, most literature reports mixed findings. Some findings showed that women directors affect board decisions positively (Setó-Pamies, 2015; Rao \& Tilt, 2016). On the contrary, some findings indicated the indirect capability of women to contribute more value to the board (Abdullah et al., 2016). Evidence concerning total women on the board as it influence performance is very limited. Nonetheless, it is expected board structure and its diversity to exert pressure on directors to engage in higher-risk disclosure, thereby affect the firm performance.

The present investigation classifies the board composition into Muslim directors and non-Muslim directors while hypothesizing that a higher number of Muslim directors on the board of directors would result in a higher quality of accounting information. According to Robinson (2007), world financial markets have experienced astonishing growth in Islamic finance. Hence Muslim directors might exhibit a more conservative behavior in running a business, thus lowering firm performance. The ethical characteristics expected of a Muslim director should encourage good corporate governance mechanism thus much lesser monitoring is needed (Alhabshi, 1994). It is established that the presence of Muslim directors on the board of directors have a significant impact on the performance of the firms and can bring the firm to its utmost performance. This study fills the gap and contributes significantly to the literature providing extensive evidence with regards to the impact of corporate governance on firms' performance especially the presence of Muslim directors in the board of directors, particularly in Jordan.

\section{Board Structure}

Board structure represents all compositions and elements of the board and how this affects the decision-making process (Jackling \& Johl, 2009; Blake, 2016). The board structures (Isik \& Ince, 2016; Nguyen et al., 2016) are extended to include board size, board independence, director ownership, total women in the board, and Muslim directors on the board. Other characteristics that are commonly considered in different studies include gender, age, experience, expertise, education, religious, and nationality (Feldman \& Montgomery, 2015; Rao \& Tilt, 2016; Aribi et al., 2018; Green \& Homroy, 2018; Hassan \& Marimuthu, 2018). The different board structure components as related to the current study are explained under the following headings.

\section{Board Size}

One of the most important factors that impact the management ability to monitor managers is the size of the board of directors (Tulung \& Ramdani, 2018). A positive connection is reported between board size (BS) and firm performance (Naseem et al., 2017). Similarly, Coles et al. (2008) revealed that a larger BS has a positive influence on corporate performance. The larger boards 
provide higher monitoring in order to enhance firm performance. Isik \& Ince (2016) found a significantly positive influence between BS and firm performance. The BS has a significant relationship between BS and different CG mechanisms on corporate performance (Dang et al., 2018). All these studies indicate that as BS increases the corporate performance increases, the cause may be that BS increases the responsibility of the boards to better manage the firm performance through proper ERM implementation. This implies that the ERM can potentially moderate between BS and performance. Small BS may be less successful in monitoring the persuasive managers.

The size of a board is noted as an essential feature that influences its efficiency. Isik \& Ince (2016) indicates that a large board may result in less effective management and decision making, whereas agency theory claims that large boards are helpful to better the monitoring of the firm. Hence, firms with large boards are more liable to freely divulge more information thereby endanger the firm and its performance. This squabble is supported by Guest (2009) and Jackling \& Johl (2009) who discovered that boards will be likely less efficient to manage firm when they expand beyond seven or eight executives. Shakir (2012) stated that a BS of 12 or 13 executives can result in more effectual management. Despite that researches have linked large BS with higher risk disclosure (Boone et al., 2007; Dang et al., 2018), empirical results seem to be inconclusive. There is no reported information on the moderating effect of ERM on BS and how this is related to firm performance.

\section{Board Independence}

Firm directors are classified into dependent and independent (Chen, 2011; Knyazeva et al., 2014). The independent directors monitoring the incentives in a particular board are sturdier when the value of human capital basically derives from their prestige. The influence of board independence on corporate performance may be reliant on the BS (Tulung \& Ramdani, 2018). The positive impact of board independence as predicted by agency theory can be bigger when the BS is bigger (Bøhren \& Staubo, 2016). A theory of board control and size also supported this view (Harris \& Raviv, 2006). High managerial skills require an in-depth understanding of the firm, its consumers, dealers, competitors, and business (Blake, 2016). Dependent directors have such expertise due to their familiarity with the firm, whereas independent directors commonly lack these qualities as a result of their far distance from the firm (Clune et al., 2014). The dependent directors can lose status by supervising (control) and form reputation by counseling (support) due to lower motivations to monitor, stronger motivations to advice compared to independent directors (Hillman \& Dalziel, 2003). Both independent and female directors have been shown to influence firm performance (Terjesen, 2016). However, studies on the effect of board independence on firm performance still remain incomplete.

Knyazeva et al. (2013) and Chen et al. (2011) suggested that the percentage of independent officers positively impacts the firm's performance. On the contrary, Savitri (2016) and Abdullah (2016) revealed that the proportion of independent officers does not impact the firm's performance. However, the results mentioning ERM moderating impact on board independence and firm performance are very scarce. 


\section{Director Ownership}

Director ownership is directly involved managerial ownership which has a significant impact on performance, both are endogenously ascertained by exogenous variations in the firm operating environment (Zhou, 2001). The ownership separation from control produces a condition where the interests of owner and manager are often differed and formerly functioned to regulate the use of power. The owner of corporate experiences a loss of control over his wealth since ownership is so largely distributed across vast numbers of stakeholders, though the stakeholder cannot use actual power to supervise directors on managerial performance (Demsetz, 1996; Bhagat \& Bolton, 2013). Managers with low ownership level may fail to increase stakeholder value since they have a motivation to consume incentives (Jensen and Meckling 1976; Zhou, 2001). Particularly, low managerial ownership level can be the best incentive procedure for the corporate. Hu \& Zhou (2008) assessed a linear relationship between board ownership and Tobin's Q, they found that Tobin's Q increases and then decreases with ownership.

These studies largely deduce the positive relationship at low levels of the director or managerial ownership, while the negative relationship at high levels of the director or managerial ownership as managers become rooted and involve in non-value maximizing interest without being disciplined by stakeholders. Conversely, these studies have not addressed the moderating role play by ERM between director ownership and firm performance. All the studies focus on the general effect of managerial ownership on firm performance. Although, Baron and Kenny (1986) proposed board equity ownership as a moderating variable that might reinforce the relationship between ERM and firm performance.

\section{Total Number of Women on the Board}

The lack of adequate women representation on boards of directors in a firm is a global phenomenon. The problem of gender diversity specifically at top of management level is catching the attention of firms cogitating the need for consequences of increasing the women participation in management positions (Aribi et al., 2018).

Encouraging gender diversity on boards of directors can enhance the decision-making process, as this entails contributing different standpoints, ideas, and evaluating different results (Green \& Homroy, 2018). By the way, the supporters of diversity or women participation on the boards showed that the heterogeneous decision-making and problem-solving approaches produce better decisions as a result of a broader range of viewpoints (Nyatichi, 2016; Sahar et al., 2018). Also, the presence of women on the boards can enhance communication, and a more comprehensive critical scrutiny of problems (Abdullah et al., 2016). Mixed-boards can also aid to thwart too risky projects as women are largely more financially risk-avert than men (Rao \& Tilt, 2016) and less overoptimistic (Terjesen et al., 2016). Thus, the total number of women on the board can be moderated by ERM to enhance firm performance.

The director ownership characteristic and concentration is likely to moderate the influence of female directors on firm performance (Setó-Pamies, 2015). The value of women's interactive characteristics as board members is possible to be improved when total numbers of women on the board are raised. Stakeholders in large firms are likely to value the supervising skills of female directors and to make a conducive environment for them to make an impact on firm performance. 
The firm characteristics and their boards define the probability of women to be nominated to the boards, their involvement shapes the CG environment and their capability to impact boards' activities and firm performance (Nyatichi, 2016). The lack of enthusiasm to nominate women on the boards deprive firm owners and its stakeholders from the potential economic benefits of female directors (Aribi et al., 2018). Studies on a total number of women on the board of directors as it affected by ERM to improve firm performance are unreported.

\section{Muslim Directors on the Board}

Islamic organizations, whether business, governmental, or none profitable firms, operate within the Sharia restrictions (Mollah et al., 2017; Abdul Rahman et al., 2018). Islamic economics as a discipline applies the injunctions of the Sharia or Islamic laws in dealing with the allocation of scarce resources for individual and collective achievements of spiritual, moral, and material wellbeing (Johl and Cooper, 2015).

Muslim directors on the board, similar to the total number of women on the board, has a positive and significant influence on corporate performance (Hadi et al., 2018). The Muslim directors can function effectively on boards of firms when working with the majority group of other religious groups. It is believed that Muslim directors in the majority of countries such as Jordan, Yemen, Iraq, Saudi, etc. can make a significant impact to the firm performance due to their religious belief which regulated the economics, moral, and dealings (Ibrahim \& Alam, 2018). As most recently reported that the more diversified a board is, in term of religion or gender, the greater the chance for corporate performance (Hassan \& Marimuthu, 2018). Muslim directors (both men and women) involvement at the board top level can improve the risk-taking behavior of managers and enhance the internal tasks of their firms as well as performance (Mollah et al., 2017). With regards to risktaking behavior, it is suggested that the ERM has potential to moderate between the numbers of Muslim directors on the board and corporate performance, though this moderation has never been reported in the literature.

\section{Moderating Variable}

A moderator variable is a third variable that impacts the strength of the relationship between an independent and dependent variable (Matthew \& Ann, 2017). In a relationship, if S is the predictor variable (first variable) and $\mathrm{T}$ is a resultant variable (second variable), then $\mathrm{Q}$ is the moderator variable (third variable) that influences the relationship of S and T (Baron \& Kenny, 1986; Kim et al., 2001). In the case of this current study, the ERM act as a moderator variable between the board structure and corporate performance. The moderator variable is introduced to determine the strength or weakness of this relationship, which can be measured both qualitatively and quantitatively (Baron and Kenny, 1986; Fairchild et al., 2009; Ahmed\& Manab, 2016b).

\section{Justification for a Moderator}

The board of directors as part of board structure is the advocates of risk management in a corporate and has the final decision about the risk management implementation (Dabari \& Saidin, 2016b; Annamalah et al., 2018). Several studies have been carried out on factors that influence ERM implementation in the firms (Ahmed \& Manab, 2016a; Dabari \& Saidin, 2016b; Tasmin \& Muazu, 2017; Annamalah et al., 2018). These reports identified numerous variables that affect ERM implementation and also employed different measures to investigate the level of ERM 
implementation. However, they all neglected or overlooked the moderating role of ERM plays in the relationship between the board structures and corporate performance.

Furthermore, ERM has been considered as one of the most significant problems bordering corporate management in the contemporary periods. It is promoters consider that incorporating all corporate risks in a single ERM can improve board of directors and long-term corporate performance (Nair et al., 2014; Soliman et al., 2018; Yang et al., 2018). Therefore, consistent with Baron and Kenny (1986), the ERM is introduced in the present study (as a moderator) with the expectation of determining and improving the relationship between board structure and corporate performance. Since the moderating variable is a variable that alters the direction or strength of a relationship between independent and dependent variables (Sekaran \& Bougie, 2016; Matthew \& Ann, 2017), the ERM will fit well to act as a moderator. Conceptually, this moderating role of ERM may produce better results for better firm performance through appropriate regulation of its board structure.

\section{Firm Performance}

Firm performance is an indicator that aids to assess and measure how a firm succeeds in achieving its business objectives in fulfilling the need of all its stakeholders (Johl et al., 2015). In recent times, the challenges of the international business environment have reverberated the need for firms to have more interests in the success of their businesses (Zou \& Hassan, 2017). Recent scandals had exposed circumstances where firms involved in unscrupulous accounting tactics to overlook relevant information about corporates' financial data (Carson, 2003; Giroux, 2008). This called for an investigation on a long-term solution for CG mechanisms that may improve the performance of a firm. This can be achieved through appropriate measurement of firm performance parameters.

Different researches have used different performance indicators to measure corporate performance (Carton et al., 2010). Murphy et al. (1996) reported 71 performance parameters that have been employed by investigators to measure both financial and non-financial performance. The investigators often use financial measures in most cases to describe the corporate performance. Return on Investment, Return on Assets, Return on Sale, Return on Equity, and Tobin's Q are some of the frequently used parameters to measure performance (Alzharani et al., 2011; Saeidi et al., 2015; Abdullah \& Shukor, 2017; Green \& Homroy, 2018; Yang et al., 2018). In more inclusive valuation, firms have recourse to the application of both financial and non-financial performance measures.

Studies conducted on the relationship between board structures and corporate performance has yielded inconclusive results (Jackling \& Johl, 2009; Blake, 2016). Studies found a positive relationship between CG mechanisms and corporate performance (Abdullah, 2016; Hadi et al., 2016), while other studies reported a negative relationship between CG mechanisms and corporate performance (Hillman \& Dalziel, 2003; Chen, 2011). Further, the internal competition within the boards is another factor that is vital considering when the relationship between board structure and firm performance as affected by ERM is being examined. This is in addition to the factors such as the total number of women on the board, the number of Muslim directors on the board, and the

size of the board. All these have an impact on the moderating role play by ERM in the relationship between board structure and firm performance. 


\section{Propositions}

The present study is proposing a research framework (Figure 1) where ERM is used in the framework to moderate between the board structures (board size, board independence, director ownership, total number of women on the board, and Muslim directors on the board) and the corporate performance thereby improve the robustness of risk management in an organization and its value. Based on the literature review in this study, and the inconsistencies found as well as the justifications for ERM introduction as a moderator, the following propositions are hence proposed according to the following hypotheses.

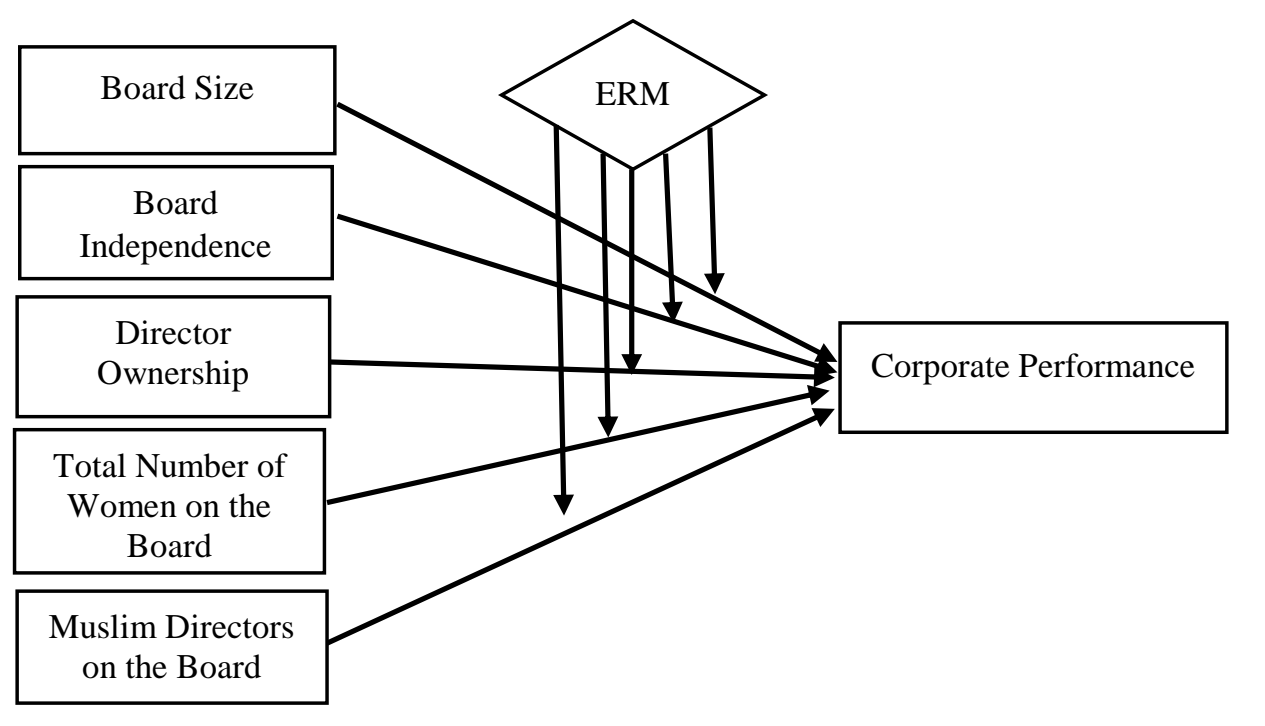

H1: The effect of Board Size on Corporate Performance is moderated by Enterprise Risk Management.

H2: The effect of Board Independence on Corporate Performance is moderated by Enterprise Risk Management.

H3: The effect of Director Ownership on Corporate Performance is moderated by Enterprise Risk Management.

H4: The effect of Total Women on the Board on Corporate Performance is moderated by Enterprise Risk Management.

H5: The effect of Muslim Directors on the Board on Corporate Performance is moderated by Enterprise Risk Management.

\section{Conclusion}

This study contributes to the knowledge and understanding of ERM use as moderating variable to enhance corporate performance and stakeholders' value. The findings showed that ERM has strong potential to moderate the relationship between board structures and firm performance. The finding 
also indicated that this moderating effect has a strong impact on corporate performance as it affected each of the board structures under this study.

\section{Reference}

Abdul Rahman, R., Hj Omar, N., Rahman, A., \& Muda, R. (2018). Islamic ethical values of corporate top leadership and real earnings management. International Journal of Law and Management, (just-accepted), 00-00.

Abdullah, M., \& Shukor, Z. A. (2017). The Comparative Moderating Effect of Risk Management Committee and Audit Committee on the Association Between Voluntary Risk Management Disclosure and Firm Performance. Jurnal Pengurusan (UKM Journal of Management), 51.

Abdullah, S. N. (2016). Corporate governance mechanisms and the performance of Malaysian listed firms. Corporate Ownership \& Control, 14(1-2), 384-398.

Abdullah, S. N., Ismail, K. N. I. K., \& Nachum, L. (2016). Does having women on boards create value? The impact of societal perceptions and corporate governance in emerging markets. Strategic Management Journal, 37(3), 466-476.

Affes, H., \& Sardouk, H. (2016). Accounting conservatism and corporate performance: The moderating effect of the board of directors. Journal of Business and Financial Affairs, 5(2), $1-8$.

Ahmed, I., \& Manab, N. A. (2016a). Moderating role of board equity ownership on the relationship between enterprise risk management implementation and firms performance: A proposed model. International Journal of Management Research and Reviews, 6(1), 21.

Ahmed, I., \& Manab, N. A. (2016b). Moderating Effects of Board Equity Ownership on the Relationship between Enterprise Risk Management and Firms Performance: Data Screening and Measurement Model. benefits, 7(6).

Alzharani, M., Madya, P. Ahmad, A and Aljaaidi, K. (2011). An Empirical Investigation of Factors Associated with Firm Performance: Evidence from Kingdom of Saudi Arabia. International Conference on E-business, Management, and Economics Analysis, 25 (4), 30-36.

Anderson, R. C., Mansi, S. A., \& Reeb, D. M. (2004). Board Characteristics, Accounting Report Integrity, and Cost of Debt. Journal of Accounting and Economics, 37(3), 315-342.

Annamalah, S., Raman, M., Marthandan, G., \& Logeswaran, A. K. (2018). Implementation of Enterprise Risk Management (ERM) Framework in Enhancing Business Performances in Oil and Gas Sector. Economies, 6(1), 4.

Aribi, Z. A., Alqatamin, R. M., \& Arun, T. (2018). Gender diversity on boards and forward-looking information disclosure: evidence from Jordan. Journal of Accounting in Emerging Economies, 8(2), 205-222.

Armeanu, D. Ş., Vintilă, G., Gherghina, Ş. C., \& Petrache, D. C. (2017). Approaches on Correlation between Board of Directors and Risk Management in Resilient Economies. Sustainability, 9(2), 173.

Baron, R. M., \& Kenny, D. A. (1986). The moderator-mediator variable distinction in social Psychological research: Conceptual, strategic, and statistical considerations. Journal of Personality and Social Psychology, 51, 1173-1182. 
Bashir, A., \& Asad, M. (2018). Moderating Effect of Leverage on the Relationship between Board Size, Board Meetings, and Performance: A Study on Textile Sector of Pakistan. American Scientific Research Journal for Engineering, Technology, and Sciences (ASRJETS), 39(1), 19-29.

Battaglia, F., Fiordelisi, F., \& Ricci, O. (2016). Enterprise Risk Management and Bank Performance: Evidence from Eastern Europe during the Financial Crisis. In Risk Management in Emerging Markets: Issues, Framework, and Modeling (pp. 295-334). Emerald Group Publishing Limited.

Berger, A. N., Imbierowicz, B., \& Rauch, C. (2016). The roles of corporate governance in bank failures during the recent financial crisis. Journal of Money, Credit and Banking, 48(4), 729-770.

Bhagat, S., \& Bolton, B. (2013). Director ownership, governance, and performance. Journal of Financial and Quantitative Analysis, 48(1), 105-135.

Blake, A. (2016). Dynamic directors: Aligning board structure for business success. Springer.

Bøhren, Ø., \& Staubo, S. (2016). Mandatory gender balance and board independence. European Financial Management, 22(1), 3-30.

Boniface U, Ibe IG. Enterprise risk management and performance of Nigeria's brewery industry. Developing Country Studies 2012; 2(10): 60-67.

Boone, A. L., Field, L. C., Karpoff, J. M., \& Raheja, C. G. (2007). The determinants of corporate board size and composition: An empirical analysis. Journal of Financial Economics, 85(1), 66-101.

Bosse, D. A., \& Phillips, R. A. (2016). Agency theory and bounded self-interest. Academy of Management Review, 41(2), 276-297.

Bromiley, P., McShane, M., Nair, A., \& Rustambekov, E. (2015). Enterprise risk management: Review, critique, and research directions. Long range planning, 48(4), 265-276.

Bromiley, P., McShane, M., Nair, A., \& Rustambekov, E. (2015). Enterprise risk management: Review, critique, and research directions. Long range planning, 48(4), 265-276.

Callahan, C., \& Soileau, J. (2017). Does Enterprise risk management enhance operating performance? Advances in accounting, 37, 122-139.

Carson, T. L. (2003). Self-interest and business ethics: Some lessons of the recent corporate scandals. Journal of Business Ethics, 43(4), 389-394.

Carton, R. B., \& Hofer, C. W. (2010). Organizational financial performance: Identifying and testing multiple dimensions. Academy of Entrepreneurship Journal, 16(2), 1.

CAS (Casualty Actuarial Society, 2003). Overview of Enterprise Risk Management. Retrieved from http://www.casact.org/research/erm/overview.pdf

Chen, H. L. (2011). Does board independence influence the top management team? Evidence from strategic decisions toward internationalization. Corporate Governance: An International Review, 19(4), 334-350.

Clune, R., Hermanson, D. R., Tompkins, J. G., \& Ye, Z. (2014). The nominating committee process: A qualitative examination of board independence and formalization. Contemporary Accounting Research, 31(3), 748-786. 
Cohen, J., Krishnamoorthy, G., \& Wright, A. (2017). Enterprise Risk Management and the Financial Reporting Process: The Experiences of Audit Committee Members, CFO s, and External Auditors. Contemporary Accounting Research, 34(2), 1178-1209.

Coles, J. L., Daniel, N. D., \& Naveen, L. (2008). Boards: Does one size fit all? Journal of financial economics, 87(2), 329-356.

COSO, I. I. (2004). Enterprise risk management. Integrated Framework. assets.hcca-info.org

Dabari, I. J., \& Saidin, S. Z. (2016a). A Moderating role of Board Characteristics. International Journal of Economics and Financial, (6), S4.

Dabari, I. J., \& Saidin, S. Z. (2016b). A Moderating Role of Board Characteristics on Enterprise Risk Management Implementation: Evidence from the Nigerian Banking Sector. International Journal of Economics and Financial Issues, 6(4S).

Dang, C., Li, Z. F., \& Yang, C. (2018). Measuring firm size in empirical corporate finance. Journal of Banking \& Finance, 86, 159-176.

Demsetz, H. (1996). The Structure of Ownership and the Theory of the Firm. The Economic Nature of the Firm: A Reader, 26, 345.

Du, K. (2018). The impact of multi-channel and multi-product strategies on firms' risk-return performance. Decision Support Systems, 109, 27-38.

Fairchild, A. J., \& MacKinnon, D. P. (2009). A general model for testing mediation and moderation effects. Prevention Science, 10(2), 87-99.

Feldman, E. R., \& Montgomery, C. A. (2015). Are incentives without expertise sufficient? Evidence from Fortune 500 firms. Strategic Management Journal, 36(1), 113-122.

Florio, C., \& Leoni, G. (2017). Enterprise risk management and firm performance: The Italian case. The British Accounting Review, 49(1), 56-74.

Fuzi, S. F. S., Halim, S. A. A., \& Julizaerma, M. K. (2016). Board independence and firm performance. Procedia Economics and Finance, 37, 460-465.

Giroux, G. (2008). What went wrong? Accounting fraud and lessons from the recent scandals. Social research, 1205-1238.

Green, C. P., \& Homroy, S. (2018). Female directors, board committees, and firm performance. European Economic Review, 102, 19-38.

Guest, P. M. (2009). The impact of board size on firm performance: evidence from the UK. The European Journal of Finance, 15(4), 385-404.

Hadi, A. R. A., Suryanto, T., \& Hussain, M. A. (2016). Corporate Governance Mechanism on the Practice of International Financial Reporting Standards (IFRS) among Muslim Entrepreneurs in Textile Industry-The Case of Malaysia. International Journal of Economic Perspectives, 10(2), 164-170.

Harris, M., \& Raviv, A. (2006). A theory of board control and size. The Review of Financial Studies, 21(4), 1797-1832.

Hassan, R., \& Marimuthu, M. (2018). Bridging and bonding: having a Muslim diversity on corporate boards and firm performance. Journal of Islamic Accounting and Business Research, 9(3), 457-478.

Hermalin, B.E. \& Weisbach, M.S. (1988). The Determinants of Board Composition', RAND Journal of Economics, 19(4), 589-606. 
Hillman, A. J., \& Dalziel, T. (2003). Boards of directors and firm performance: Integrating agency and resource dependence perspectives. Academy of Management review, 28(3), 383-396.

Hu, Y., \& Zhou, X. (2008). The performance effect of managerial ownership: Evidence from China. Journal of Banking \& Finance, 32(10), 2099-2110.

Ibrahim, M. H., \& Alam, N. (2018). Islamic economics and Islamic finance in the world economy. The World Economy, 41(3), 668-673.

Isik, O., \& Ince, A. R. (2016). Board size, board composition, and performance: An investigation on Turkish banks. International Business Research, 9(2), 74-84.

Jackling, B., \& Johl, S. (2009). Board structure and firm performance: Evidence from India's top companies. Corporate Governance: An International Review, 17(4), 492-509.

Jensen, M. C. (1993). The Modern Industrial Revolution, Exit and the Failure of Internal Control Systems. Journal of Finance, 48(3), 831-880.

Jensen, M. C., \& Meckling, W. H. (1976). Theory of the firm: Managerial behavior, agency costs, and ownership structure. Journal of financial economics, 3(4), 305-360.

Jizi, M., \& Nehme, R. (2018). Board monitoring and audit fees: the moderating role of CEO/chair dual roles. Managerial Auditing Journal, 33(2), 217-243.

Johl, S. K., Kaur, S., \& Cooper, B. J. (2015). Board characteristics and firm performance: Evidence from Malaysian public listed firms. Journal of Economics, Business, and Management, 3(2), 239-243.

Khan, S. N., \& Ali, E. I. E. (2017). The Moderating Role of Intellectual Capital between Enterprise Risk Management and Firm Performance: A Conceptual Review. American Journal of Social Sciences and Humanities, 2(1), 9-15.

Kim, J. S., Kaye, J., \& Wright, L. K. (2001). Moderating and mediating effects in causal models. Issues in Mental Health Nursing, 22(1), 63-75.

Knyazeva, A., Knyazeva, D., \& Masulis, R. W. (2013). The supply of corporate directors and board independence. The Review of Financial Studies, 26(6), 1561-1605.

Lee, J. H., Choi, C., \& Kim, J. M. (2012). Outside directors' social capital and firm performance: A complex network approach. Social Behavior and Personality: an international journal, 40(8), 1319-1331.

Lu, D. (2004). Methods and systems for enterprise risk auditing and management. U.S. Patent Application No. 10/640,213.

Matthew S. F., \& Ann M. A. (2017). Moderator Variables. Methods and Approaches in Psychology. Industrial and Organizational Psychology. DOI:10.1093/acrefore/9780190236557.013.86

Miloš Sprčić, D., Kožul, A., \& Pecina, E. (2017). Managers' Support-A Key Driver behind Enterprise Risk Management Maturity. Zagreb international review of economics \& business, 20(SCI), 25-39.

Mollah, S., Hassan, M. K., Al Farooque, O., \& Mobarek, A. (2017). The governance, risk-taking, and performance of Islamic banks. Journal of financial services research, 51(2), 195-219.

Murphy, G. B., Trailer, J. W., \& Hill, R. C. (1996). Measuring performance in entrepreneurship research. Journal of business research, 36(1), 15-23. 
Nair, A., Rustambekov, E., McShane, M., \& Fainshmidt, S. (2014). Enterprise risk management as a dynamic capability: A test of its effectiveness during a crisis. Managerial and Decision Economics, 35(8), 555-566.

Naseem, M. A., Xiaoming, S., Riaz, S., \& Rehman, R. U. (2017). Board attributes and financial performance: the evidence from an emerging economy. The Journal of Developing Areas, 51(3), 281-297.

Nguyen, P., Rahman, N., Tong, A., \& Zhao, R. (2016). Board size and firm value: Evidence from Australia. Journal of Management \& Governance, 20(4), 851-873.

Nyatichi, V. (2016). Moderating Influence of Board Diversity and Directors Compensation on Corporate Governance Structure and Financial Performance of the companies listed on the Nairobi Stock Exchange. International Journal of Accounting Research, 5:1.

Pagach, D., \& Warr, R. (2011). The characteristics of firms that hire chief risk officers. Journal of Risk and Insurance, 78(1), 185-211.

Rao, K., \& Tilt, C. (2016). Board composition and corporate social responsibility: The role of diversity, gender, strategy and decision making. Journal of Business Ethics, 138(2), 327347.

Reddy, K., Locke, S., \& Scrimgeour, F. (2010). The efficacy of principle-based corporate governance practices and firm financial performance: An empirical investigation. International Journal of Manc gerial Finance, 6(3), 1 90-2 19.

Saeidi, S. P., Sofian, S., Saeidi, P., Saeidi, S. P., \& Saaeidi, S. A. (2015). How does corporate social responsibility contribute to firm financial performance? The mediating role of competitive advantage, reputation, and customer satisfaction. Journal of business research, 68(2), 341-350.

Sahar, E., Zulkifli, N., \& Zakaria, Z. (2018). A Moderated Mediation Model for Board Diversity and Corporate Performance in ASEAN Countries. Sustainability, 10(2), 556.

Savitri, E. (2016). Corporate governance mechanism and the moderating effect of independency on the integrity of financial reporting. Investment Management and Financial Innovations, 4(13), 68-74.

Sekaran, U., \& Bougie, R. (2016). Research methods for business: A skill building approach. John Wiley \& Sons.

Setó-Pamies, D. (2015). The relationship between women directors and corporate social responsibility. Corporate Social Responsibility and Environmental Management, 22(6), 334-345.

Shakir, R. (2012). Board Size, Board Compositıon, and Property Firm Performance.

Soliman, A., Mukhtar, A., \& Shubita, M. (2018). The Long-term Relationship Between Enterprise Risk Management and Bank Performance: the missing link in Nigeria. Banks and Bank Systems, 13, 1.

Tahir, I. M., \& Razali, A. R. (2011). The Relationship between enterprise risk management (ERM) and firm value: Evidence From Malaysian public listed companies. International journal of economics and management sciences, 1(2), 32-41.

Tasmin, R., \& Muazu, H. M. (2017). Moderating Effects of Risk Management Function on Determinants of Enterprise Risk Management Implementation in Malaysian Oil and Gas Sector: A Conceptual Framework. Journal of Technology Management and Business, 4(2). 
Terjesen, S., Couto, E. B., \& Francisco, P. M. (2016). Does the presence of independent and female directors impact firm performance? A multi-country study of board diversity. Journal of Management \& Governance, 20(3), 447-483.

Tulung, J. E., \& Ramdani, D. (2018). Independence, Size, and Performance of the Board: An Emerging Market Research.

Yang, S., Ishtiaq, M., \& Anwar, M. (2018). Enterprise Risk Management Practices and Firm Performance, the Mediating Role of Competitive Advantage and the Moderating Role of Financial Literacy. Journal of Risk and Financial Management, 11(3), 35.

Yermack, D. (1996). Higher market valuation of companies with a small board of directors. Journal of financial economics, 40(2), 185-211.

Zemzem, A., \& Ftouhi, K. (2013). Moderating Effects of Board of Directors on the Relationship between Tax Planning and Bank Performance: Evidence from Tunisia. European Journal of Business and Management, 5(32), 148-154.

Zhou, X. (2001). Understanding the determinants of managerial ownership and the link between ownership and performance: comment. Journal of financial economics, 62(3), 559-571. 